\title{
The Pathogen Construct in Risk Analysis
}

Jerry S. Busby, Department of Management Science, Lancaster University, Lancaster, United Kingdom

Hongliang Zhang, Department of Industrial Engineering and Management, College of Engineering, Peking University, Beijing, China

\section{ABSTRACT}

Project risk analysis has traditionally emphasized the analysis of external threats. Here we argue that internal decisions and structures are more fundamental, because they determine which external events pose risks to project management. A "pathogen" metaphor is used to understand these internal sources of risk, in an analysis of failure in two sets of projects that lie on the border between the private and public sectors. This analysis goes beyond earlier work on organizational pathogens by treating them as subjective interpretations, not objective conditions. The study suggests that the more insidious risks to which a project is exposed involve different project members holding contradictory beliefs about what is pathogenic and what is protective

KEYWORDS: projects; risk; pathogens; failure; subjectivity

Project Management Journal, Vol. 39, No. 3, 86-96 (c) 2008 by the Project Management Institute

Published online in Wiley InterScience

(www.interscience.wiley.com)

DOI: 10.1002/pmj.20070

\section{INTRODUCTION}

$\mathrm{R}$ isk in its more formal interpretations is a statistical concept of events that happen to someone or something. It is primarily concerned with threatening conditions and events, their probabilities and consequences. Analysis of these threats is usually followed by a search for ways of making them tolerable in some way. This basic stress on external threat and probabilistic consequences is found in most approaches to project risk analysis (for example, Chapman \&Ward, 1997; Cooper \& Chapman, 1987; Hertz \& Thomas, 1983). But it has certain limitations, and in particular makes little room for the idea that organizations' encounters with risk are as much encounters with their own qualities and deficiencies as they are encounters with external circumstances (Hutter \& Power, 2005). Baker's (2002) analysis of the failure of the Firefly project shows how decisions made early in the project built in a strong predisposition to breakdown, especially the choice of a commercial off-the-shelf (COTS) product, which then had to be modified. Unfortunately, because it was a COTS product, it was then inadequately tested. Thus, an analysis of events without an analysis of organizational capacities and built-in predispositions is only half an analysis. This is related to the inherently circular nature of knowledge about risk (Adams, 1995). When risk bearers know about a risk, they generally modify their behavior, which in turn modifies the risk, so they need to look inward to their own choices and response as much as outward to external threats. And they need to see their understanding of risk at any time as needing to be continually updated.

These limitations suggest that the emphasis in project risk analysis should be shifted from the exterior toward the interior. It is not just that "internally generated risks" (Barber, 2005) are important, but that even apparently external risks are risks because of interior structures, decisions, or arrangements. A project becomes vulnerable to labor unrest in a supplier, for instance, because that supplier was chosen, and that supplier was chosen because a process of choosing suppliers was decided upon, or inherited, or in some other way built into a project organization. This points to a similar line of thinking developed by Reason (1990a, 1990b), who argued that there was an analogy between the origin of biological illness and the breakdown of complex technological systems. At certain times, external circumstances combine with "resident pathogens" to overcome a system's defenses and bring about its breakdown. The defining aspect of these metaphorical pathogens is that they predate the conditions that trigger the breakdown, and are generally more stable and more observable-if you go looking for them-than the triggering events. A decision to cut back on resources devoted to maintenance, for instance, may not produce an immediate catastrophe but sets up the conditions in which a particular occurrence, such as an adverse weather event or an operator error, does produce catastrophe. 
A study by Busby and Hughes (2004) attempted to apply the pathogen metaphor to project failures, to characterize more precisely what "pathogens" amounted to in the project management context. What was pathogenic turned out to be routine elements of organization-like particular practices or conventions-that produced breakdowns of some kind in particular circumstances. But the study also concluded that things appearing to be "pathogenic" could just as readily be interpreted as being adaptive or even protective. Thus, for example, the practice of ring-fencing funds for a particular task can be protective in the sense that it ensures that task receives sufficient resources but pathogenic if it denies project managers the flexibility to respond to unforeseen calls for funding in other tasks. Moreover, the consequences of failure were often ambivalent. Failure was disruptive and led to losses of time and money in the short term, yet it also contributed to improvements and sometimes innovations in the longer term. It disadvantaged some stakeholders but not others. It therefore seems unreasonable to treat "pathogens" as objective entities and better to see the "pathogen" label as a subjective interpretation. The label may be applied to an objective entity, like an organizational practice, but it represents just one perspective on how that entity contributes to the working (or breakdown) of the organization. Kirby's (1996) case study showed how quite different perspectives on failure are taken by different people.

This analysis of pathogens in projects as subjective interpretations, not objective conditions, reflects a general line of thinking in the risk field. "Risk" itself is seen as an overlay on the world rather than something objectively observable about it (Jasanoff, 1993). Perceptions of risk (for example, Slovic, 1987) become as important and consequential as objective expert analysis. And different groups are seen as selecting particular risks for attention based on their cultures, not the objective properties of the risks themselves (for example, Douglas, 1992; Douglas \& Wildavsky, 1983; Schwarz \& Thompson, 1990). The subjectivity of pathogens in projects also fits with the idea that projects are "multi-nodal" and combine many perspectives and contradictions (Ivory \& Alderman, 2005). In fact, project organizations seem especially likely to experience pathogens as being subjective. In permanent organizations engaged in routine activity, the various members have an indefinite amount of time, and an indefinite repetition of activity, in which to appreciate the differences in their interpretations of events. But the relative temporariness, uniqueness, and novelty of project organizations (Söderlund, 2003; Turner \& Müller, 2003) make it more likely that discrepant interpretations about what is pathogenic and what is protective go unnoticed.

The purpose of this study was therefore to examine "pathogens" in project organizations as a specifically subjective concept. We wanted to find out how the same entity could be construed as being both pathogenic and adaptive, why different participants might have different interpretations, and how discrepancy in these interpretations could itself be problematic. It seemed likely that the most insidious kind of risk to a project-the least well understood and potentially the most difficult to manage if it materializedwas the kind that involved contradictory interpretations. This in turn suggested that risk analysis should not simply be a consensual analysis of threats and consequences. It should also involve inspecting how different actors have come up with different views on the best responses to these threats, and how some of these responses are themselves threats in other actors' eyes.

As there is no proper received definition of "pathogen" in this context, our working definition is that a pathogen is some entity with the following properties:
- It is inherently the cause of some recognizable organizational breakdown or failure-for example, an inability to complete a project or significant conflict (perhaps litigation) among project participants.

- It is created by social actors, and not merely an intrinsic vulnerability-for example, an authority structure, contract or agreement, procedure, or practice.

- It only becomes clearly problematic and part of an observable breakdown after a prolonged period-for example, it may exist at the start of a project but only bring about failure in later stages.

- It only becomes problematic upon the occurrence of some triggering event or condition, which it predatesfor example, a contractual agreement that impedes recovery from an error or environmental event.

In one of the cases we refer to in this article, a decision was made to finance a project from a particular revenue stream. This decision turned out to be "pathogenic" when, as a result of low demand, these revenues were much lower than expected, and the consequence was a considerable crisis for the project. The decision was effectively a pathogen, as it was inherently the cause of the crisis, creating the vulnerability to a revenue stream. It was produced by the project actors, since they could perfectly well have made a different decision. It existed in the system, as it were, for some time before its problematic quality became obvious. And it caused a crisis only when a triggering condition (the shortfall in revenue) came into being. Yet labeling this decision pathogenic is clearly subjective, because it was also interpreted as being protective: it avoided the risk associated with the project making unexpected demands on other sources of finance (such as public taxation). We suggest it is particularly important in project risk analysis to discover such contradictory interpretations, because the contradictions 
The Pathogen Construct in Risk Analysis

impede the process of dealing with such risks as they materialize. We also suggest that this kind of analysis is completely general. Even when risks are external, uncontrollable physical events like earthquakes, it is reasonable to look for entities built into the project organization as the origin of the threat: a decision to locate facilities in vulnerable regions of the world, the practice of allowing subcontractors to organize their own supply chains, and so on. It is such decisions and practices that can be thought of as being pathogens.

\section{Methodology}

The methodology involved a case study (for example, Eisenhardt, 1989, 1991; Stake, 1995; Yin, 2003a, 2003b). A case study was particularly indicated because our interest was in a subject where the boundaries between phenomenon and context were blurred, and where there were many more variables of interest than data points (Yin, 2003a). We were interested in understanding the dynamics present within single settings (Eisenhardt, 1989) and we had no opportunity for experimental control or manipulation (Benbasat, Goldstein, \& Mead, 1987). Our concern was with the particularity and complexity of activity in specific circumstances (Stake, 1995). And we needed a method that was both sensitive to social construction and also "detached" (Easterby-Smith, Thorpe, \& Lowe, 2002).

The aim was to investigate "pathogens" in a setting where we hoped different perspectives on project risk would be especially stark. We therefore looked to projects that involved some mixture of private- and publicsector organizations, in settings that were undergoing substantial structural change. In the United Kingdom, a candidate set of cases was provided by a small number of "public-private partnership" projects that had been investigated by the central government's audit office. As large infrastructure projects, generally, they had the qualities discussed by Miller and Hobbs (2005): they were visible and contestable and

\begin{tabular}{|l|l|}
\hline Case & \multicolumn{1}{c|}{ Source } \\
\hline The Libra IT System for Magistrates' Courts & NAO (2003), HC 327 \\
\hline The Channel Tunnel Rail Link & NAO (2001), HC 302 \\
\hline The Royal Armouries Museum in Leeds & NAO (2001), HC 103 \\
\hline The Benefits Payment Card Project & NAO (2000), HC 85? \\
\hline Table 1: National Audit Office reports used in the case studies. \\
\hline
\end{tabular}

raised conflicts for individual public officials who were both involved in them and attempting to preserve a role as independent guardians of the public good. In China, a candidate set of cases was provided by projects being undertaken by state-owned enterprises. These are organizations that-very broadly—are intended to act like private corporations but still suffer the constraints and cultures found in the centrally planned economy. As Boardman (2001) argued about four years before this study was undertaken,

.. . China has a relatively concentrated industrial structure ... dominated by many inefficient, badlystructured and poorly-run SOEs [state-owned enterprises]. The distribution of resources is distorted in that government authorities still play a role in the allocation of investment funds, and capital does not necessarily move to sectors where it is most productive ... SOE managers are de-facto enjoying more autonomy than otherwise formally indicated. But they are doing so largely not by design, but because property rights are poorly defined. The result is that ... SOEs are protected from competition in product and factor markets by policy barriers to entry or similar institutional constraints....

Thus in both sets of cases there were aspects of organization that essentially belonged to the public sector and aspects that belonged in the private sector. And in both settings the organizations were having to become accustomed to new ways of financing projects and-in particular- dealing with risk, while taking place in a state of continuing and incomplete readjustment.

The U.K. cases were intended as a pilot study. Our dataset consisted of four reports from the U.K. National Audit Office on the conduct of specific projects, shown in Table 1. These four were selected because they were perceived as being particularly problematic. The aim in the pilot was to determine how feasible it was to identify "pathogens" from informants' accounts (in this case, the NAO authors), and whether it was also possible to make reasonable conjectures about the perspectives of other actors whose behaviors were described. A particular advantage of this kind of secondary data was that it was detailed and wideranging. People from a number of disciplines were involved in the investigations, and the investigators had sufficient credibility to obtain opinions and knowledge from many actors. At the same time there were substantial limitations. The data seemed to emphasize the early phases of projects, provided relatively little analysis of the relationship between project organizations and permanent organizations, stressed decisions more than routines, and sometimes provided relatively little historical explanation. The fact that they were largely retrospective in nature also means that they might not present a satisfactory view of the uncertainties that confronted actors at the time. And it is possible they will project a narrow and particular version of reality (see, for example, Brown, 2004, 2005).

The Chinese cases were taken from a set of unstructured interviews 
conducted in four sibling corporations, all operating in the petrochemicals industry. The choice of corporation was essentially a convenience sample. Within these corporations, a sample of 60 managers was constructed for the interviews, shown in Table 2. The sampling was partly convenience (those managers known to our contact) and partly stratified (we requested interviews with people at several levels of seniority). The interviews were conducted by one of the authors, in Chinese, and the informants were asked to describe specific examples of what they regarded as being project failures, and to explain what they believe caused them, particularly managerial and organizational factors. There was no attempt to predetermine a set of criteria for objectively judging the existence of failure, so what was a failure was what the interviewee construed as a failure. Again the aim was to (1) identify in the interviewees' accounts a particular construction of how breakdowns had taken place and (2) identify alternative constructions of those same events. Interviews were recorded and transcribed in Chinese, and relevant parts were translated into English before analysis.

Analysis of both datasets was grounded, involving a step-by-step inspection of each case to find descriptions that met the defining conditions of a "pathogen" laid out in the Introduction. With both datasets, it was generally straightforward to identify what the informants interpreted as being pathogenic, and it was also generally possible to identify contradictory interpretations of other actors. Nonetheless, these inferences have to be regarded as provisional-our interpretations of other people's interpretations - and the study needs to be seen as being exploratory. Finally, an attempt was made to generate taxonomies both of the pathogens and of the factors that determined what the informants and actors interpreted as being pathogenic.

\section{Findings}

\section{Some Examples}

Table 3 summarizes examples of pathogens inferred from the first dataset (the National Audit Office reports) in a highly condensed form. The first column shows the project and the second column the entity that was described in such a way in the reports that it fitted our definition of pathogen. The next two columns show the triggering condition and outcome. The final column indicates the alternative viewpoint that appeared to explain why the pathogenic entity had come into being, and why it had been interpreted as being adaptive or protective rather than pathogenic. In most cases, in fact, the pathogen reflects an adaptation to some risk other than the one that materialized. For example, in the third entry, a choice not to revise business processes at the time a new system was being introduced was interpreted as being pathogenic by the source. But it had been interpreted by the actors as being protective, on the basis that to have changed business processes, especially at a time other changes were going on, was itself risky.

Table 4 similarly shows pathogens inferred from the Chinese SOE interviews.

\section{Two Taxonomies}

The full set of pathogens inferred from the two datasets was used to develop taxonomies, first of the pathogens as they were described, and second of the factors that appeared to influence the interpretations of what was pathogenic and what was adaptive.

Table 5 is a basic taxonomy of the entities that were construed as being pathogenic. There was considerable latitude in deciding just what the pathogen was in any given case. Often the pathogenic entities were taken to be "artifacts": man-made objects (not necessarily physical ones) like norms and standards. But it was equally possible to say the manner in which the artifacts were applied was what was pathogenic, or the process by which it had been designed or created, rather than the artifact itself. Similarly, some of the pathogens were task characteristics, like "complexity" and "novelty." But it was equally possible to say that the decision to engage in such a task was what was really pathogenic, not the task itself. At a detailed level of analysis, therefore, the choice of what it is that is pathogenic is somewhat arbitrary.

Table 6 is a taxonomy of what appears to influence the construction of pathogens. The numbers are inconsistent with those in Table 5 because there can be multiple influences on the construction of a given pathogen. The main categories of influence are actors' roles, their knowledge, their dispositions, and the context, and there are various subcategories under each. It is hard to interpret the numbers and hard to compare NAO and SOE cases because of differences in the information sources. For instance, it seems more likely personal attributions will arise in interviews than in public reports. Moreover, this is a highly subjective analysis. We have no objective information about why the actors construed a particular risk as being important and a particular entity as being pathogenic-we have only the informants' descriptions. And we have no objective information about why the informants drew their conclusions about what was pathogenic. Nonetheless, the table indicates that there is a considerable variety of influences on people's constructions of what is pathogenic. A construction or interpretation of a pathogen is the result of an uncertain process in which people synthesize a diverse set of factors relevant to their perceptions of risk in projects.

\section{Discussion}

\section{Why Protection Can Be Pathogenic and Vice Versa}

The NAO cases point to several reasons why a practice that turns out to be pathogenic might have been seen as 


\section{The Pathogen Construct in Risk Analysis}

\begin{tabular}{|c|c|c|c|}
\hline Role & Domain & Role & Domain \\
\hline Firm A & & Firm C (cont.) & \\
\hline Middle manager & Construction management & Junior manager & Project and quality management \\
\hline Middle manager & Project management & Department head & Project and procurement management \\
\hline Middle manager & Project management & Junior manager & Project accountant \\
\hline Junior manager & Quality management & Junior manager & Procurement management \\
\hline Department head & Project feasibility analysis/planning & Engineer & Design \\
\hline Middle manager & Project planning & Engineer & Design \\
\hline \multirow[t]{2}{*}{ Junior manager } & Project feasibility analysis & Engineer & Design and management \\
\hline & & Middle manager & R\&D management \\
\hline Firm $B$ & & Junior manager & Purchasing management \\
\hline Engineering manager & Project management & Junior manager & Purchasing management \\
\hline Middle manager & Project feasibility analysis/planning & Department head & Project feasibility analysis and planning \\
\hline Junior manager & Project management & Middle manager & Project feasibility analysis \\
\hline Production manager & Engineering management & Middle manager & Project planning \\
\hline Production manager & Engineering management & Junior manager & Project feasibility analysis \\
\hline Middle manager & Project feasibility analysis/planning & Junior manager & Project feasibility analysis \\
\hline Middle manager & Technology management & Junior manager & Project feasibility analysis \\
\hline Head of engineers & Project manager & Junior manager & Project planning \\
\hline Middle manager & Project planning & Junior manager & Project coordination \\
\hline Design engineer & Technology management & Middle manager & Technology and market survey \\
\hline Design engineer & Technology management & Junior manager & Document management \\
\hline Design engineer & Technology management & Junior manager & ERP project management \\
\hline Department head & R\&D management & Junior manager & Project management \\
\hline \multirow[t]{2}{*}{ Vice-senior engineer } & Project planning and management & & \\
\hline & & Firm D & \\
\hline Firm C & & Vice-senior engineer & Project feasibility analysis and planning \\
\hline Installation manager & Project management & Middle manager & Project planning \\
\hline Safety manager & Safety management & Middle manager & Project planning \\
\hline Vice-senior engineer & Project management & Middle manager & Project feasibility analysis \\
\hline Middle manager & Engineering management & Project manager & Project management \\
\hline Middle manager & Design management & Project manager & Project management \\
\hline Junior manager & Engineering management & Project manager & Project management \\
\hline Project manager & Project and quality management & Junior manager & Project planning \\
\hline
\end{tabular}




\begin{tabular}{|c|c|c|c|c|}
\hline Case & $\begin{array}{l}\text { Pathogen as Seen } \\
\text { by Informant }\end{array}$ & $\begin{array}{l}\text { Triggering Event } \\
\text { or Condition }\end{array}$ & Consequence & $\begin{array}{l}\text { Alternative } \\
\text { Constructions }\end{array}$ \\
\hline $\begin{array}{l}\text { Benefits Card } \\
\text { system }\end{array}$ & $\begin{array}{l}\text { Decision to operate bidding } \\
\text { on the basis that the new } \\
\text { system is a straightforward } \\
\text { extension of a prior system } \\
\text { and the related decision to } \\
\text { avoid spending large funds } \\
\text { on a prebid pilot }\end{array}$ & $\begin{array}{l}\text { The extension of a prior } \\
\text { system turned out to be } \\
\text { infeasible, as the } \\
\text { requirements of the new } \\
\text { system were a lot more } \\
\text { complex }\end{array}$ & $\begin{array}{l}\text { Poor developer } \\
\text { performance, } \\
\text { serious slippage, } \\
\text { and cost overrun }\end{array}$ & $\begin{array}{l}\text { Contractor minimizes } \\
\text { risk of losing bid by } \\
\text { bidding on assumption } \\
\text { of low cost and } \\
\text { complexity; } \\
\text { client minimizes risk } \\
\text { of large investment } \\
\text { in pilot }\end{array}$ \\
\hline 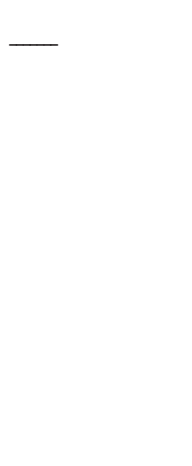 & $\begin{array}{l}\text { Formulation of requirements } \\
\text { only at a high level in } \\
\text { response to growing concern } \\
\text { about the duration and cost of } \\
\text { the bidding process }\end{array}$ & $\begin{array}{l}\text { Project complexity was } \\
\text { underestimated, and project } \\
\text { planning was not feasible } \\
\text { for predefined timetable and } \\
\text { level of functionality }\end{array}$ & $\begin{array}{l}\text { Poor developer } \\
\text { performance, } \\
\text { serious slippage, } \\
\text { and cost overrun }\end{array}$ & $\begin{array}{l}\text { The risks were seen } \\
\text { as an overextended } \\
\text { bidding and } \\
\text { procurement process, } \\
\text { displacing concerns } \\
\text { about subsequent } \\
\text { development; there } \\
\text { was also a school of } \\
\text { thought that detailed } \\
\text { requirements that } \\
\text { would preclude } \\
\text { innovation }\end{array}$ \\
\hline $\begin{array}{l}\text { Magistrates } \\
\text { Court system }\end{array}$ & $\begin{array}{l}\text { Choice not to revise business } \\
\text { processes in parallel with the } \\
\text { new system }\end{array}$ & $\begin{array}{l}\text { Different business processes } \\
\text { across the patch created } \\
\text { high complexity for system } \\
\text { developers }\end{array}$ & $\begin{array}{l}\text { Poor developer } \\
\text { performance, } \\
\text { slippage, and cost } \\
\text { overrun }\end{array}$ & $\begin{array}{l}\text { Other changes were } \\
\text { going on, and changes } \\
\text { to business processes } \\
\text { were seen as risky }\end{array}$ \\
\hline- & $\begin{array}{l}\text { Change in development } \\
\text { model from sequential } \\
\text { waterfall to parallel joint } \\
\text { application development }\end{array}$ & $\begin{array}{l}\text { Underdeveloped and } \\
\text { unsatisfactory functional } \\
\text { specification }\end{array}$ & $\begin{array}{l}\text { Integration } \\
\text { problems }\end{array}$ & $\begin{array}{l}\text { Contractor saw the } \\
\text { change as reducing } \\
\text { risk of overrun }\end{array}$ \\
\hline $\begin{array}{l}\text { Royal } \\
\text { Armouries } \\
\text { project }\end{array}$ & $\begin{array}{l}\text { Private-sector firm built and } \\
\text { ran the museum with funds } \\
\text { it raised; public contributions } \\
\text { were to be small and specific }\end{array}$ & $\begin{array}{l}\text { Revenues were insufficient } \\
\text { to meet costs and service } \\
\text { the firm's debt }\end{array}$ & $\begin{array}{l}\text { Government } \\
\text { department took } \\
\text { over running of } \\
\text { museum in a } \\
\text { restructuring }\end{array}$ & $\begin{array}{l}\text { Government } \\
\text { department saw } \\
\text { decision as maximally } \\
\text { transferring risk } \\
\text { away from it }\end{array}$ \\
\hline $\begin{array}{l}\text { Channel } \\
\text { Tunnel Rail } \\
\text { Link }\end{array}$ & $\begin{array}{l}\text { Government transferred } \\
\text { assets to contractor well } \\
\text { before it achieved second- } \\
\text { stage financing } \\
\text { (against normal } \\
\text { practice), which was } \\
\text { contingent on strong } \\
\text { revenues from Eurostar }\end{array}$ & $\begin{array}{l}\text { Lower-than-expected } \\
\text { revenues from Eurostar }\end{array}$ & $\begin{array}{l}\text { Public sector } \\
\text { recovered } \\
\text { liabilities from } \\
\text { LCR }\end{array}$ & $\begin{array}{l}\text { Two-stage financing } \\
\text { was needed to } \\
\text { minimize risk that no } \\
\text { private-sector firm } \\
\text { would be willing to } \\
\text { finance the project }\end{array}$ \\
\hline- & $\begin{array}{l}\text { Government had direct } \\
\text { agreement with contractor's } \\
\text { bankers to service the debt } \\
\text { in early stages }\end{array}$ & $\begin{array}{l}\text { Lower-than-expected } \\
\text { revenues from Eurostar } \\
\text { U.K. }\end{array}$ & $\begin{array}{l}\text { Government } \\
\text { needed to take } \\
\text { on LCR's } \\
\text { outstanding } \\
\text { liabilities }\end{array}$ & $\begin{array}{l}\text { Government } \\
\text { saw private financing } \\
\text { as being risk limiting, } \\
\text { but the private sector } \\
\text { saw the risk as being } \\
\text { unusually high } \\
\text { without government } \\
\text { underwriting }\end{array}$ \\
\hline
\end{tabular}




\section{The Pathogen Construct in Risk Analysis}

\begin{tabular}{|c|c|c|c|c|}
\hline Case & $\begin{array}{l}\text { Pathogen as Seen } \\
\text { by Informant }\end{array}$ & $\begin{array}{l}\text { Triggering Event or } \\
\text { Condition }\end{array}$ & Consequence & $\begin{array}{l}\text { Alternative } \\
\text { Constructions }\end{array}$ \\
\hline $\begin{array}{l}\text { Development } \\
\text { of new } \\
\text { petrochemicals- } \\
\text { based products } \\
\text { and equipment }\end{array}$ & $\begin{array}{l}10 \% \text { reduction of } \\
\text { project budget by parent } \\
\text { company and inflexible } \\
\text { demand by parent to } \\
\text { adhere to initial plans }\end{array}$ & $\begin{array}{l}\text { Large increase in } \\
\text { steel price led to } \\
\text { procurement of low- } \\
\text { quality materials }\end{array}$ & $\begin{array}{l}\text { Poor } \\
\text { performance of the } \\
\text { new equipment }\end{array}$ & $\begin{array}{l}\text { Parent company limited } \\
\text { its exposure by restricting } \\
\text { budget and curtailing } \\
\text { flexibility }\end{array}$ \\
\hline 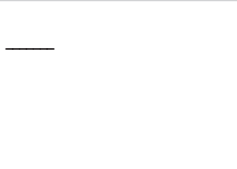 & $\begin{array}{l}\text { Delegation of } \\
\text { market/technology survey } \\
\text { without commitment of } \\
\text { full funding of expenses }\end{array}$ & $\begin{array}{l}\text { Delegatee reports } \\
\text { infeasibility without } \\
\text { full investigation }\end{array}$ & $\begin{array}{l}\text { Potentially promising } \\
\text { project was lost }\end{array}$ & $\begin{array}{l}\text { Delegator perceived risk in } \\
\text { committing higher level of } \\
\text { expenses to a single survey }\end{array}$ \\
\hline $\begin{array}{l}\text { Development of } \\
\text { new compound }\end{array}$ & $\begin{array}{l}\text { Practice of starting } \\
\text { development using } \\
\text { brochure information on } \\
\text { equipment needed for } \\
\text { the work }\end{array}$ & $\begin{array}{l}\text { Provider of } \\
\text { equipment changed } \\
\text { detailed specification }\end{array}$ & $\begin{array}{l}\text { Rework and delay } \\
\text { in development } \\
\text { process }\end{array}$ & $\begin{array}{l}\text { Concurrency needed to } \\
\text { avoid risk of exceeding } \\
\text { lead time specified by } \\
\text { parent company, and } \\
\text { risk of losing potential } \\
\text { market share }\end{array}$ \\
\hline $\begin{array}{l}\text { IS department } \\
\text { contracted to } \\
\text { supply to } \\
\text { another } \\
\text { company a } \\
\text { foreign } \\
\text { technology for } \\
\text { which it acted } \\
\text { as agent }\end{array}$ & $\begin{array}{l}\text { Choice to decouple } \\
\text { supplier and client } \\
\text { contracts, making a one- } \\
\text { off payment to the foreign } \\
\text { supplier but agreeing to } \\
\text { stage payments with the } \\
\text { client; and making } \\
\text { technology commitments } \\
\text { to the client exceeding } \\
\text { those made by the supplier }\end{array}$ & $\begin{array}{l}\text { Foreign supplier } \\
\text { restructured and } \\
\text { became unable to } \\
\text { enhance the } \\
\text { technology }\end{array}$ & $\begin{array}{l}\text { Financial losses } \\
\text { on the project and } \\
\text { loss of credit } \\
\text { standing }\end{array}$ & $\begin{array}{l}\text { Risk was perceived to lie in } \\
\text { the loss of the project with } \\
\text { the client unless terms } \\
\text { favorable to the client were } \\
\text { accepted }\end{array}$ \\
\hline $\begin{array}{l}\text { Automation } \\
\text { project in } \\
\text { oil refiner }\end{array}$ & $\begin{array}{l}\text { Finance department } \\
\text { insisted on conventional } \\
\text { commercial arrangements } \\
\text { when firm wanted to } \\
\text { outsource maintenance }\end{array}$ & $\begin{array}{l}\text { Loss of internal } \\
\text { personnel qualified } \\
\text { to perform } \\
\text { maintenance }\end{array}$ & $\begin{array}{l}\text { Project } \\
\text { discontinued }\end{array}$ & $\begin{array}{l}\text { Finance department limits } \\
\text { risk by avoiding unusual } \\
\text { arrangements; operating } \\
\text { departments limit risk by } \\
\text { adopting novel } \\
\text { arrangements }\end{array}$ \\
\hline $\begin{array}{l}\text { Integration stage } \\
\text { in a project to } \\
\text { apply a new } \\
\text { technology to } \\
\text { improve } \\
\text { production } \\
\text { efficiency }\end{array}$ & $\begin{array}{l}\text { Decision to omit } \\
\text { integration testing }\end{array}$ & $\begin{array}{l}\text { Inadequate } \\
\text { consistency of } \\
\text { parts }\end{array}$ & Failure of the whole & $\begin{array}{l}\text { Avoidance of this step } \\
\text { seems to reduce lead time } \\
\text { and possibly budget risk }\end{array}$ \\
\hline
\end{tabular}

protective. First, risks change with time over the course of a project, and managing risk at one time cannot be separated from risk at another. For example, an organization can minimize risk in a pilot project by making the pilot a small, limited exercise. But this tends to increase risk in the subsequent parts of a project. Second, risks in different parts of a project cannot be completely separated. For example, in the Magistrates Court system, the client was reluctant to impose uniform business processes on the semi-independent courts because other changes were going on at the time. But this then created a complexity risk for the project. This kind of effect seems inevitable when the project organization is a network of actors rather than a hierarchy (Hellgren \& Stjernberg, 1995). Third, actors in a project do not have arbitrary choices about how they distribute and transfer risk. For example, in some of 


\begin{tabular}{|c|c|c|c|}
\hline \multirow[b]{2}{*}{ Category } & \multicolumn{2}{|c|}{ Quantity } & \multirow[b]{2}{*}{ Description } \\
\hline & NAO reports & $\begin{array}{l}\text { Chinese } \\
\text { interviews }\end{array}$ & \\
\hline Artifact & 17 & 27 & $\begin{array}{l}\text { Objects such as norms and } \\
\text { standards, salary structure, } \\
\text { organization structure, project plans } \\
\text { and project contract, and so on }\end{array}$ \\
\hline Behavior & 22 & 22 & $\begin{array}{l}\text { Observable organizational and } \\
\text { individual actions }\end{array}$ \\
\hline Routine & 3 & 31 & $\begin{array}{l}\text { Recurrent patterns in activity, } \\
\text { practice, or cognition }\end{array}$ \\
\hline $\begin{array}{l}\text { Task } \\
\text { characteristics }\end{array}$ & 5 & 7 & $\begin{array}{l}\text { Attributes such as novelty, distance, } \\
\text { duration, complexity, and } \\
\text { completeness }\end{array}$ \\
\hline Technology & & 3 & $\begin{array}{l}\text { Aspects of a technology } \\
\text { such as intrusiveness and quality }\end{array}$ \\
\hline
\end{tabular}

Table 5: A categorization of project pathogens.

the cases the public-sector organization saw private-sector construction and financing as limiting risk to the public purse, but the private sector saw the risk to them as being somehow unacceptable. So the public-sector organization had to give undertakings that limited this risk, and these undertakings became pathogenic becauseperhaps unsurprisingly - they returned the risk right back to the public sector.

Quite similar points emerged from the Chinese SOE cases. There were cases, for instance, where an actor limited his or her risk by adhering to standard procedures or practices, which increased risk as seen by other actors when it created inflexibility and closed off possible lines of action. And there were cases where different parts or stages of a project interacted. So limiting the risk of losing the contract with a client led to risk in implementationfor example, where undertakings had to be given to the client that could not be matched with undertakings obtained from a contractor. Similarly, avoiding certain stages of work was risk-limiting at one level and riskincreasing at another. It is tempting to say that this kind of connection is obvious, and actors are being foolish. How could anyone imagine that bypassing specification tasks or integration tasks would reduce rather than increase risk to a project? But it is unlikely that this could be clearly seen at the time. Being engaged in a particular stage of a project selects certain risks for a project manager's attention, and the priority becomes dealing with these risks rather than worrying about how widely the

\begin{tabular}{|c|c|c|c|c|}
\hline \multirow{2}{*}{$\begin{array}{l}\text { Main } \\
\text { Category }\end{array}$} & \multirow[b]{2}{*}{ Subcategory } & \multicolumn{2}{|c|}{ Quantity } & \multirow[b]{2}{*}{ Description } \\
\hline & & NAO & $\overline{\text { SOE }}$ & \\
\hline \multirow[t]{4}{*}{ Role } & Area & 40 & 18 & Working on different parts of a project \\
\hline & Level & & 4 & Working at different levels of hierarchy \\
\hline & Discipline & & 6 & Working in different technical disciplines \\
\hline & Goal & 19 & 26 & Having different specific goals \\
\hline \multirow[t]{3}{*}{ Context } & Sector & 1 & 1 & Working in different economic sectors \\
\hline & Culture & & 9 & Working in different organizational or national cultures \\
\hline & Stressors & 9 & 3 & Working under different pressures to perform \\
\hline \multirow[t]{3}{*}{ Knowledge } & Experiential knowledge & 8 & 14 & Having had different specific experiences \\
\hline & Formal knowledge & 4 & 10 & Having differences in education or training \\
\hline & Local knowledge & & 5 & Having different specific beliefs about a situation \\
\hline \multirow[t]{2}{*}{ Disposition } & Personality & & 3 & Having different personal attributes \\
\hline & Attitude & 4 & 16 & Having different attitudes toward relevant phenomena \\
\hline
\end{tabular}


way of dealing with them will ramify into other stages of the project.

\section{The Origins of Different Perspectives}

Table 6 indicated what appeared to influence actors' interpretations of what was pathogenic. Much of this analysis was conjecture, because the data offered only indirect evidence in most cases. But it suggested that it was a mix of the internal and external that led people to see certain entities as being the source of risk and others as being a way of mitigating risk. The internal factors were their knowledge, understandings, training, and so on on the one hand and their dispositions and attitudes on the other. The external factors were their roles and domains, influences from the industry they worked in, and the particular circumstances of the project. A significant proportion of these factors could be collected under the heading of "identity," and identity then becomes the key influence that leads people to interpret certain entities as being pathogenic. It is the way in which project managers' basic attitudes to risk and failure, their particular understanding of a project and the stage it has reached, and the role they play that all come together to form their identity and shape their view of an entity as pathogenic or protective. It is a similar argument to March's (1994) work on how actors' identities influence their interpretations and decision making.

These factors also converge in expectations of blame. It seems inevitable that actors' constructions of what is "pathogenic" would be based on what they might be blamed for. Blameworthy events become highly specific risks to an individual, and the origins of these events-whether practices, artifacts, decisions, and so onbecome relevant pathogens. There is an argument that blame will be especially prominent in project organizations. The autonomy that managers experience in projects (Bresnen, Goussevskaia, \& Swan, 2004; Sydow, Lindkvist, \&
DeFillippi, 2004) suggests that blame is likely to be much less equivocal than in other kinds of organization, where "systemic" failures are hard to link to particular people. It is harder for project managers who are perceived to be autonomous to explain away failure to circumstances beyond their control. Similarly, the emphasis in project organizations on tasks (Lundin \& Söderholm, 1995) indicates that task failure is more likely to be followed by blame. In permanent organizations, engaged in repetitive operations, the failure of specific tasks on specific occasions is less important than the maintenance of long-term cohesion. Thus, project managers can expect blame more than most other managers, and the prospect of blame will be more central to their judgments.

\section{The Real Job of Risk Analysis}

We suggested earlier that there is a more insidious kind of risk than the face-value risks typically identified in project risk analyses. This is the risk that problematic events become especially intractable because actors' interpretations of risk are contradictory. It was not just that different actors do not see the same risks, but that the risks in one actor's eyes are the means of managing risk in another's eyes. So the actors are attached to their points of view because they suit their identities, and reflect their expectations of blame, and also because they are the solutions to their problems. An actor for whom ring-fenced funding is a protection has a strong incentive to play down the extent to which that ring-fenced funding is also a risk. This implies that different actors will not automatically understand and legitimize other actors' views about risk, and that an important part of risk analysis should be to discover these discrepancies. All this is especially important in projects, because they are temporary organizations that tend not to have repeated experiences. This is similar to Kirby's (1996) point that project managers should recognize the existence of different perspectives before they jeopardize a project's success. It is also somewhat similar to Weick and Roberts's (1993) principle that actors should exercise "heedfulness" in their dealings with risk.

A practical way of analyzing the subjectivity of risk understandings is (1) to get the main actors in a project to identify risks, perform the kind of analysis that suits them, and plan mitigating measures, and then (2) to get them to analyze each other's analyses, looking not particularly for gaps in their own analysis but contradictory interpretations of the same entity. They then need to come together to explore the implications, particularly (1) whether their differences will hamper the management of risk as it materializes and (2) whether there are alternative ways of managing risks that avoid the problem of creating other risks. The most important element of this exercise is to avoid seeking consensus, since this will only obscure the differences that would emerge if the project started to fail. At some point, the actors need to agree on how to get on with the concrete business of the project, but they should be clear not only about the risks this will create for them, but also the risks it creates for others-and the risks that will come from others trying to manage their risks. Genus (1997) remarked, in connection with his study of the Channel Tunnel project, "The adversarial nature of contractual relations ... may be said to stem from [the parties'] different perspectives and objectives." We would argue that an understanding of different perspectives might produce less adversarial relationships-not least because there is a greater appreciation of how mutually confounding actions also mean selfconfounding actions.

\section{Conclusion}

Our thesis is that risk analysis should incorporate the insight that a project organization's experience of risk is as 
much the experience of its own characteristics and limitations as it is of external events. We have suggested the use of the "pathogen" metaphor as a way of emphasizing those causes of organizational breakdown that are built into projects at their inception. We have also suggested that different actors will sometimes have very different interpretations of what is pathogenic and what is adaptive, and that this kind of discrepancy poses particularly insidious risks. A number of cases were examined in this study based on (1) secondary data on U.K. public-private partnership projects and (2) interview data on Chinese state-owned enterprise projects. These offered plenty of support for the thesis that the more fundamental causes of breakdown were typically decisions, or practices, or other basic entities within a project, not external events. It was these that turned particular external events or conditions into threats or risks. The cases also supported the principle that pathogens existed as such only from certain viewpoints. One person's pathogen was sometimes another's protection; a protection at one point in a project became a pathogen at a later point. The main practical implication was that project risk analysis should involve an analysis of how discrepancies among different actors' constructions of the relevant "pathogens" might arise.

The study had a number of limitations. Although it drew on data about project organizations in the United Kingdom and China, the methods were dissimilar, and this precluded comparisons between the two settings. A comparison of how project managers understand risk differently in the two cultures would be a worthwhile subject for further study. The work was also exploratory and limited to particular industries, so a confirmatory study that extends across a wider range of industries is suggested. It would also be interesting to include some demographic analysis, assessing whether there is a particular relationship between the experience of individual managers, for example, and their understandings of project risk. Finally, there was no attempt to assess how the principles for a better approach to risk analysis would work in practice. Nonetheless, it draws attention to the basic idea that risk originates in the way organizations see the world, rather than the world itself, and that recognizing this is an important step in getting beyond the limitations of traditional risk analysis.

\section{Acknowledgment}

Many thanks are due to the reviewers of an earlier draft of this article.

\section{References}

Adams, J. (1995). Risk. London: UCL Press.

Baker. B. (2002). The fall of the Firefly: An assessment of a failed project strategy. Project Management Journal, 33, 53-57.

Barber, R. B. (2005). Understanding internally generated risks in projects. International Journal of Project Management, 23, 584-590.

Benbasat, I., Goldstein, D. K., \& Mead, M. (1987). The case research strategy in studies of information systems. MIS Quarterly, 11, 368-386.

Boardman, H. G. (2001). The business(es) of the Chinese state. World Economy, 24, 849-875.

Bresnen, M., Goussevskaia, A., \& Swan, J. (2004). Embedding new management knowledge in project-based organizations. Organization Studies, 25, 1535-1555.

Brown, A. D. (2004). Authoritative sensemaking in a public inquiry report. Organization Studies, 25, 95-112.

Brown, A. D. (2005). Making sense of the collapse of Barings Bank. Human Relations, 58, 1579-1604.

Busby, J. S., \& Hughes, E. J. (2004). Projects, pathogens and incubation periods. International Journal of Project Management, 22, 425-434.
Chapman, C., \& Ward, S. (1997). Project risk management: Processes, techniques, and insights. Chichester, UK: John Wiley \& Sons.

Cooper, D. F., \& Chapman, C. B. (1987). Risk analysis for large projects: Models, methods and cases. Chichester, UK: John Wiley \& Sons.

Douglas, M. (1992). Risk and blame. London: Routledge.

Douglas, M., \& Wildavsky, A. (1983). Risk and culture: An essay on the selection of technological and environmental dangers. Berkeley, CA: University of California Press.

Easterby-Smith, M., Thorpe, R., \& Lowe, A. (2002). Management research: An introduction (2nd ed.). London: Sage.

Eisenhardt, K. M. (1989). Building theories from case study research. Academy of Management Review, 14, 532-550.

Eisenhardt, K. M. (1991). Better stories and better constructs: The case for rigor and comparative logic. Academy of Management Review, 16, 620-627.

Genus, A. (1997). Managing large-scale technology and inter-organizational relations: The case of the Channel Tunnel. Research Policy, 26, 169-189.

Hellgren, B., \& Stjernberg, T. (1995). Design and implementation in major investments-A project network approach. Scandinavian Journal of Management, 11, 377-394.

Hertz, D. B., \& Thomas, H. (1983). Risk analysis and its application. New York: John Wiley \& Sons.

Hutter, B., \& Power, M. (2005). Organizational encounters with risk: An introduction. In B. Hutter \& M. Power (Eds.), Organizational encounters with risk (pp. 1-32). Cambridge, UK: Cambridge University Press.

Ivory, C., \& Alderman, N. (2005). Can project management learn anything from studies of failure in complex systems? Project Management Journal, 36, 5-16. 
The Pathogen Construct in Risk Analysis

Jasanoff, S. (1993). Bridging the two cultures of risk analysis. Risk Analysis, 13, 123-129.

Johnson, B. B., \& Covello, V.T. (1987). The social and cultural construction of risk: Essays on risk selection and perception. Dordrecht, the Netherlands: Reidel.

Kirby, E. G. (1996). The importance of recognizing alternative perspectives: An analysis of a failed project. International Journal of Project Management, 14, 209-211.

Lundin, R. A., \& Söderholm, A. (1995). A theory of the temporary organization. Scandinavian Journal of Management, 11, 437-455.

March, J. G. (1994). A primer on decision making: How decisions happen. New York: The Free Press.

Miller, R., \& Hobbs, B. (2005).

Governance regimes for large complex projects. Project Management Journal, $36,42-50$.

Reason, J. (1990a). Human error. New York: Cambridge University Press.

Reason, J. (1990b). The contribution of latent human failures to the breakdown of complex systems. Philosophical Transactions of the Royal Society of London, Series B, 327, 475-484.

Schwarz, M., \& Thompson, M. (1990). Divided we stand: Redefining politics, technology and social choice. New York: Harvester Wheatsheaf.

Slovic, P. (1987). Perception of risk. Science, 236, 280-285.

Söderlund, J. (2003). Building theories of project management: Past research, questions for the future. International Journal of Project Management, 22, 183-191.

Stake, R. E. (1995). The art of case study research. Thousand Oaks, CA: Sage.

Sydow, J., Lindkvist, L., \& DeFillippi, R. (2004). Project-based organizations, embeddedness and repositories of knowledge (editorial). Organization Studies, 25, 1475-1489.

Turner, J. R., \& Müller, R. (2003). On the nature of the project as a temporary organization. International Journal of Project Management, 21, 1-8.

Weick, K. E., \& Roberts, K. H. (1993). Collective mind in organizations:
Heedful interrelating on flight decks. Administrative Science Quarterly, 38, 357-381.

Yin, R. K. (2003a). Applications of case study research (2nd ed.). Thousand Oaks, CA: Sage.

Yin, R. K. (2003b). Case study research: Design and methods (3rd ed.). Thousand Oaks, CA: Sage.

Jerry S. Busby is a senior lecturer in the Department of Management Science, Lancaster University. His research interests are in risk analysis, risk management, and organizational failure. He has worked in various engineering industries, and has a PhD from Lancaster University, an MSc from Imperial College London, and an MA from Cambridge University.

Hongliang Zhang is an assistant professor in the Department of Industrial Engineering and Management, Peking University. His current research activities focus on the subjective nature of risk and organizational failure. He has a PhD in management science from Lancaster University. 